\title{
UTILITY TO CONSUMERS AND CONSUMER ACCEPTANCE OF INFORMATION ON BEEF LABELS IN SOUTHERN CHILE
}

\author{
Berta Schnettler M. ${ }^{1 *}$, Roberto Silva F. ${ }^{1}$, and Néstor Sepúlveda B. ${ }^{1}$
}

\begin{abstract}
Credence attributes (production system, animal welfare, traceability, among others) have acquired importance for meat products in developed countries, representing information that must be included on label. A personal survey was administered to 770 consumers in the Bío-Bío and La Araucanía Regions, Chile, to determine the utility of information contained on the label and acceptance of information referred to as credence attributes, as well as to distinguish different consumer segments. The packaging and expiry dates were the most useful aspects of the current information. The greatest degree of agreement with respect to information that should be included was a quality seal, type of animal, handling regarding animal welfare, production system and feeding. Using cluster analysis, three segments were distinguished. The largest (49.2\%) agreed most strongly with including information about feeding, transport conditions, slaughtering, traceability, and production system. The second group (34.4\%) was indifferent to information about transport, slaughter and traceability. The smallest segment (16.4\%) disagreed with including information on slaughtering. Therefore, the information currently present on meat labels was useful for consumers, who would also value having information on the credence attributes associated with cattle production, such as production system, feeding and animal welfare.
\end{abstract}

Key words: beef, label, animal welfare, production systems, traceability.

\section{INTRODUCTION}

Article 2 of the General Regulation of the System of Classification of Cattle and the Classification, Brand and Sale of Beef (SAG, 2008), with subsequent modifications, establishes that "Slaughterhouses have the obligation to classify all bovine cattle they receive in the process of slaughter, in conformity with the terms established by the official Chilean standard NCH 1423 Of. 94. Likewise, once the corresponding sanitary inspection has been conducted, cuts of meat should be classified according to the parameters established in NCH 1306 Of. 93. Deboning should be undertaken according to the cuts, the names and identification of which are outlined in NCH 1596. Of 1999". Section 3 of the same regulation refers to the sale of meat to the public: "Meat from previously classified animals should be duly classified and branded according to official Chilean standards set out in Article 2", a requirement that also regulates imported products. Under the same title, Article 10 establishes that all businesses

${ }^{1}$ Universidad de La Frontera, Facultad de Ciencias Agropecuarias y Forestales, Casilla 54-D, Temuco, Chile. *Corresponding author (bschnett@ufro.cl).

Received: 06 June 2008.

Accepted: 15 July 2008. selling meat to the public should inform customers on an ongoing basis of the official categories of meat for sale, which according to the Article 11, also applies to packaged meat. This article also stipulates that "The product should be kept in the original packaging, sealed, with a label that indelibly indicates the category and cut of the meat, the date of slaughter (day, month and year) and the name, number address of the meat-packer. However, when it is necessary to subdivide the cuts, the new package should indicate the origin, understood as the country, the meatpacker, the date of slaughter, and the category and name of the cut. Finally, Article 12 states: "the labels referred to in the previous article can contain other information, as long as this does not lead to confusion or fraud with regard to the packaged product".

Consumers increasingly demand quality products, a concept that is changing rapidly, especially in relation to meat (Grunert and Valli, 2001). The international literature reports the increasing importance of attributes of quality related to the credence of food products (Corcoran et al., 2001; Bernués et al., 2003a). Credence attributes are focused mainly on the quality of the production process, which is to say, on extrinsic attributes rather than intrinsic attributes of the meat (such as flavor, color, smell), which should be reported through labeling (Bernués et al., 2003a). Product 
labeling plays several functions: identification, qualification, description, promotion (Kotler, 1997), differentiation from competition (Altmann, 1997), encouragement of consumer confidence in quality and education on eating habits and health care (Caswell and Mojduszka, 1996). Studies have shown that meat-packaging labels can improve consumer perception of product quality (Verbeke and Viaene, 1999; Bredahl, 2004).

The information that consumers in developed countries value most relates to nutritional (Bernués et al., 2003a; Roosen et al., 2003; Bredahl, 2004; Oliver et al., 2006), the presence of a quality seal (Verbeke et al., 2000; Verbeke and Ward, 2006), expiration date (Verbeke et al., 2000; Bernués et al., 2003a; Verbeke and Ward, 2006) and the name of the cut (Verbeke et al., 2000; Bernués et al., 2003a). However, there is growing interest in information related to extrinsic attributes of meat: origin (Bernués et al., 2003a; 2003b; Alfnes, 2004; Olaizola et al., 2005; Oliver et al., 2006), production system (Verbeke and Viaene, 1999; Bernués et al., 2003a; 2003b; Schröder and McEachern, 2004; Olaizola et al., 2005; María, 2006), animal welfare (Verbeke and Viaene, 1999; Köbrich et al., 2001; Bernués et al., 2003b; Blokhuis et al., 2003; McEachern and Seaman, 2005; María, 2006; Napolitano et al., 2007), feeding of the animal (Glitsch, 2000; Bernués et al. 2003a; 2003b; Olaizola et al., 2005), traceability (Bernués et al., 2003a), all of which are credence attributes.

However, other authors have noted low interest among European consumers in this type of information (Verbeke et al., 2000; Verbeke and Ward, 2006) or different degrees of interest according to age (Grunert and Valli, 2001; Bernués et al., 2003a; 2003b; Alfnes, 2004; María, 2006; Verbeke and Ward, 2006), gender (Beardsworth et al., 2002; Alfnes, 2004; María, 2006), education level (Grunert and Valli, 2001; Bernués et al., 2003b; Olaizola et al., 2005; María, 2006), area of residence (Alfnes, 2004; Verbeke and Ward, 2006) and presence of children in the home (Verbeke et al., 2000; Bernués et al., 2003a). Verbeke and Viaene (1999) indicate that some consumers do not use or understand food labels.

Based on the preceding, the objective of this study was to determine the utility for consumers of the information on beef packaging labels, the level of acceptance of information relating to the production system, animal welfare and traceability, and to distinguish different consumer segments in cities with more than 100000 inhabitants in the Bío-Bío and La Araucanía Regions of Chile.

\section{MATERIALS AND METHODS}

An individual survey was carried out with a sample of 384 persons from La Araucanía Region and 386 persons from the Bío-Bío Region, Chile. The individuals sampled were responsible for purchasing meat for their respective households. The sample size was determined using the probabilistic sampling formula (Scheaffer et al., 1996) according to the population of the 2002 Census (INE, 2003), considering $95 \%$ of confidence, $5 \%$ error of estimation and maximum dispersion $(\mathrm{p}=\mathrm{q}=0.5)$, which implies expecting the highest level of variation of opinion of the total collective with respect to the mean value (Fernández, 2002). The surveys were conducted in cities with populations of more than 100000 inhabitants in the two regions, because of which in La Araucanía Region the survey was only applied in Temuco (245 347 inhabitants; $38^{\circ} 45^{\prime} \mathrm{S}, 73^{\circ} 03^{\prime} \mathrm{W}$ ), while in the Bío-Bío Region the surveyed population was distributed through proportional affixation in the cities of Chillan (161953 inhabitants, 115 subject surveyed; $36^{\circ} 60^{\prime} \mathrm{S}, 72^{\circ} 12^{\prime} \mathrm{W}$ ), Concepcion (216 061 inhabitants, 153 subjects surveyed; $36^{\circ} 77^{\prime} \mathrm{S}, 7^{\circ} 07^{\prime}$ W) and Los Angeles (166 556 inhabitants, 118 subjects surveyed; $37^{\circ} 45^{\prime} \mathrm{S}, 72^{\circ} 36^{\prime} \mathrm{W}$ ).

A questionnaire was used to gather information, in which subjects were asked closed questions about the frequency of consuming beef, whether they had read information about animal welfare (AW), whether they read labels before making purchasing meat, as well as questions to classify the survey subjects: gender, age, number and age of the members of the family group, area of residence, occupation and education level of the head of the household and ownership of 10 domestic goods. These last two variables served to determine the socioeconomic group according to Adimark (2004), corresponding to $\mathrm{ABC} 1$ (high and high middle), $\mathrm{C} 2$ (middle), C3 (low middle), D (low) and E (very low). The survey was applied at two supermarkets in each city, between October 2006 and January 2007, subsequent to the validation of the questionnaire through a pretest with $10 \%$ of the sample in Temuco. Table 1 presents the percentage distribution of the sample according to the alternative to each for the questions in the questionnaire.

A Likert scale was used (Kinnear and Taylor, 1989) with five levels ( 5 = very useful, $4=$ useful, $3=$ indifferent, $2=$ not very useful, $1=$ not useful at all) for subjects to indicate the assigned utility to eight different types of information on beef packaging labels: Packaging date, expiration date, name of the cut, appropriate cooking use of the cut, nutritional content, classification (V-C-U$\mathrm{N}-\mathrm{O}$ ), country of origin and place of slaughter. A Likert scale with five levels was used $(5=$ strongly agree, $4=$ agree, $3=$ indifferent, $2=$ disagree, $1=$ strongly disagree) for survey subjects to indicate their level of agreement with the inclusion of eight additional aspects on the label: quality seal, type of animal (cow, steer, bull, heifer, other), feed received by the animal, transportation 
Table 1. Percentage description of the sample of habitual meat buyers surveyed in supermarkets in the Bío-Bío and La Araucanía Regions, Chile. January 2007.

\begin{tabular}{|c|c|c|c|}
\hline Sample & $\begin{array}{l}\text { Bío-Bío Region } \\
\quad(\mathrm{n}=\mathbf{3 8 6})\end{array}$ & $\begin{array}{l}\text { La Araucanía Region } \\
\qquad(\mathrm{n}=384)\end{array}$ & $\begin{array}{c}\text { Total sample } \\
(\mathrm{n}=770)\end{array}$ \\
\hline & & $\%-$ & - \\
\hline Female & 67.5 & 74.5 & 72.7 \\
\hline Male & 32.5 & 25.5 & 27.3 \\
\hline$<35$ years of age & 21.5 & 33.1 & 27.2 \\
\hline $35-54$ years of age & 67.6 & 55.5 & 61.6 \\
\hline 55 years of age or older & 10.9 & 11.5 & 11.2 \\
\hline $1-2$ family members & 12.7 & 14.3 & 13.6 \\
\hline 3-4 family members & 49.1 & 57.6 & 53.2 \\
\hline 5 or more & 38.2 & 28.1 & 33.2 \\
\hline Families with children under 12 & 37.2 & 25.6 & 31.3 \\
\hline Families with children between 13 and 17 & 33.6 & 47.9 & 40.8 \\
\hline Families with only adults & 29.2 & 26.5 & 27.9 \\
\hline Business person, self-employed, agric. & 29.1 & 29.9 & 29.4 \\
\hline Private sector employee & 44.4 & 41.9 & 43.0 \\
\hline Public sector employee & 14.8 & 17.2 & 16.0 \\
\hline Retired & 9.9 & 8.9 & 9.3 \\
\hline Unemployed & 1.8 & 2.1 & 1.3 \\
\hline Primary not completed & 0.0 & 1.3 & 0.7 \\
\hline Primary completed & 0.3 & 2.8 & 1.6 \\
\hline Secondary not completed & 1.0 & 2.8 & 1.8 \\
\hline Vocational completed & 30.7 & 38.7 & 34.7 \\
\hline Vocational not completed & 16.9 & 9.5 & 13.2 \\
\hline Vocational completed or university not completed & 24.2 & 18.9 & 21.5 \\
\hline University completed or more & 26.8 & 25.9 & 26.5 \\
\hline $\mathrm{ABC} 1$ & 44.9 & 45.6 & 45.2 \\
\hline $\mathrm{C} 2$ & 40.3 & 48.2 & 44.2 \\
\hline $\mathrm{C} 3$ & 10.6 & 5.7 & 8.2 \\
\hline $\mathrm{D}$ & 3.1 & 0.5 & 1.8 \\
\hline $\mathrm{E}$ & 1.0 & - & 0.6 \\
\hline Urban & 94.3 & 99.0 & 96.6 \\
\hline Rural & 5.7 & 1.0 & 3.4 \\
\hline Eats beef daily & 14.8 & 9.1 & 11.9 \\
\hline Three times a week & 49.9 & 55.1 & 52.6 \\
\hline Once a week & 31.0 & 26.6 & 28.7 \\
\hline Occasionally & 4.4 & 9.1 & 6.8 \\
\hline Reads meat labels & 87.8 & 96.4 & 92.1 \\
\hline Doesn't read labels & 12.2 & 3.6 & 7.9 \\
\hline Has had information about AW & 36.8 & 45.7 & 41.2 \\
\hline Has not had information about AW & 63.2 & 54.3 & 58.8 \\
\hline
\end{tabular}

AW: Animal welfare.

conditions of the animal, conditions of slaughter of the animal; place where the animal was born, reared, fattened and slaughtered, production system and handling of the animal considering standards of animal welfare. The subjects had to indicate their level of agreement with each of these aspects generically, without indicating, for example, the certifying body for a quality seal or specific practices during slaughter.

This information was analyzed by means of descriptive statistics (means calculation), and ordered according to 
average values considering figures between 3.5 and 5 as a level of high utility or agreement, between 2.5 and 3.5 as a level of indifference, and under 2.5 as a level of low utility or disagreement, respectively according to the described scales of utility and agreement. Hierarchical conglomerate cluster analysis was subsequently used to distinguish consumer segments by combining the utility that they assigned to the information currently available on labels and the level of acceptance of additional information. The Ward method was used for conglomeration. The measurement of similarity among objects was squared Euclidian distance (Hair et al., 1999). The number of clusters was obtained by observation of the dendrogram and was confirmed by determining the percentage of change of the recomposed conglomeration coefficients. To describe the segments, the chi-squared test was applied for the discrete variables (social demographics, frequency of consuming beef, reading labels and access to information on AW) and variance analysis of a factor for the continuous variables with a level of confidence of $99 \%$ and $95 \%$ (Lea et al., 1997) and subsequently application of the Tukey multiple comparison test $(\mathrm{P} \leq 0.001$ or 0.05$)$. The SPSS 14.0 program (SPSS, 2005) for Windows was used.

\section{RESULTS AND DISCUSSION}

\section{Utility and consumer acceptance of information on beef package labels}

According to the five-level Likert scale (5 being very useful and 1 being not useful at all) the different themes of information on beef package labels presented values higher than 3.5 in the total sample, which corresponds to levels of utility and high utility for the consumer (Table 2). Among the themes with the highest utility are the packaging and expiration dates of the product (4.86), while a lower level of utility was given to place of slaughter of the animal (3.76). The high utility attributed to the packaging and expiration date reflects consumer concern about product freshness in a similar manner to what is reported in developed countries (Verbeke et al., 2000; Bernués et al., 2003a; Verbeke and Ward, 2006).

The high utility attributed to meat classification (4.75) and to the name of the cut (4.70) suggests that these topics are used by consumers as indicators of product quality. In effect, the name of the cut is recognized as an efficient indicator of meat quality, which is reflected in the price differences for different cuts (Bernués et al., 2003a). Although in a secondary position among the aspects of evaluated information, the high value on nutritional content (4.55) reflects consumer concern about protecting health in relation to consuming beef, which is similar to what is found in development countries (Bernués et al., 2003a; Roosen et al., 2003; Bredahl, 2004; Oliver et al., 2006). Likewise, the high utility attributed to information about the country of origin of the meat (4.50) confirms the importance of this attribute in the purchasing decision in both developed countries (Bernués et al., 2003a; 2003b; Alfnes, 2004; Olaizola et al., 2005; Oliver et al., 2006), and in Chile, according to previous studies developed by Schnettler et al. $(2004 ; 2008 \mathrm{a})$. In contrast to what was reported by Bernués et al. (2003a) in five European countries, the present study obtained a high value for information on the appropriate cooking use of the meat cut (4.48). This indicates that the surveyed consumers have a low level of knowledge on the theme, which is congruent with an earlier study carried out in Temuco by Schnettler et al. (2006), in which $50.8 \%$ of survey subjects knew of only some or no cooking applications of the beef cuts. In this context, meat retailers can play an active role by informing consumers about the quality and use of the different cuts of the animal, generating a mutual benefit.

In addition, all the topics of additional information presented means above 3.5, which implies levels of agreement on the part of the consumer (Table 2). The highest levels of agreement related to the incorporation of a quality seal and indicating the type of animal from which the meat came (4.78 and 4.71, respectively). The lowest level of agreement was obtained regarding the possibility of including the conditions of slaughter of the animal and traceability information (3.95 and 3.96, respectively). The high level of agreement about including a seal guaranteeing quality of the meat concurs with studies in developed countries in the relation to the need of consumers to have information on the quality of the product (Verbeke et al., 2000; Grunert and Valli, 2001; Verbeke and Ward, 2006). While the Regulation on the Structure and Operation of Slaughterhouses, Cold Storage Facilities and Meat Packing Plants and Minimum Fixed Equipment of such Establishments (Decree 61, FAENACAR, 2004) incorporates obligatory procedures for assuring quality and high technology in animal slaughter, this information is not known by consumer. Consequently, a seal provided by the Agricultural and Cattle Service, a body charged with enforcing the standards set out in Decree 61, would increase consumer confidence in the product.

The high level of agreement on including the type of animal, that is, if the meat comes from the slaughter of a cow, steer, bull, heifer or other animal, indicates that consumers require more detailed information than is currently provided through classification, given that in each category meat can correspond to several types of animals (i.e. category $\mathrm{C}$ considers young cows and steers). In this regard, if we consider that international studies conclude that meat quality is affected by the sex 
Table 2. Utility assigned to the information on beef labels and degree of agreement with including additional information, corresponding to the total sample and the segments obtained via cluster analysis. The Bío-Bío and La Araucanía Regions. January 2007.

\begin{tabular}{|c|c|c|c|c|c|c|}
\hline & $\begin{array}{c}\text { Total } \\
\text { sample } \\
(n=770)\end{array}$ & $\begin{array}{c}\text { Segment } \\
1 \\
(n=379)\end{array}$ & $\begin{array}{c}\underset{2}{\text { Segment }} \\
(n=126)\end{array}$ & $\begin{array}{c}\text { Segment } \\
3 \\
(n=265)\end{array}$ & $\mathbf{F}$ & Sig. ${ }^{2}$ \\
\hline \multicolumn{7}{|l|}{ Utility of the information on the label } \\
\hline Date of packaging & 4.86 & $4.89 \mathrm{a}$ & $4.91 \mathrm{a}$ & $4.78 b$ & $6.718^{*}$ & 0.002 \\
\hline Expiry date & 4.86 & $4.91 \mathrm{a}$ & $4.83 \mathrm{ab}$ & $4.81 b$ & $5.637 *$ & 0.004 \\
\hline Name of cut & 4.70 & $4.86 \mathrm{a}$ & $4.71 \mathrm{a}$ & $4.48 b$ & $45.101 * *$ & 0.000 \\
\hline Appropriate cooking use & 4.48 & $4.75 \mathrm{a}$ & $4.79 \mathrm{a}$ & $3.95 b$ & $124.775^{* *}$ & 0.000 \\
\hline Nutritional content of the meat & 4.55 & $4.66 \mathrm{a}$ & $4.58 \mathrm{ab}$ & $4.38 b$ & $15.566^{* *}$ & 0.000 \\
\hline Classification of the meat (V-C-U-N-O) & 4.75 & $4.76 \mathrm{a}$ & $4.63 b$ & $4.78 \mathrm{a}$ & $3.576^{*}$ & 0.028 \\
\hline Country of origin of the meat & 4.50 & $4.67 \mathrm{a}$ & $4.09 \mathrm{~b}$ & $4.46 \mathrm{a}$ & $25.772 * *$ & 0.000 \\
\hline Place of slaughter of the animal & 3.76 & $4.34 \mathrm{a}$ & $3.31 b$ & $3.15 b$ & $116.047^{* *}$ & 0.000 \\
\hline \multicolumn{7}{|l|}{ Agreement with inclusion of information on the label } \\
\hline Quality seal & 4.78 & $4.85 \mathrm{a}$ & $4.52 b$ & $4.82 \mathrm{a}$ & $28.201 * *$ & 0.000 \\
\hline Type of animal (cow, steer, bull, heifer, other) & 4.71 & $4.78 \mathrm{a}$ & $4.49 b$ & $4.71 \mathrm{a}$ & $13.677 * *$ & 0.000 \\
\hline Feed received by the animal & 4.41 & $4.55 \mathrm{a}$ & $4.21 b$ & $4.30 \mathrm{~b}$ & $15.165 * *$ & 0.000 \\
\hline Transportation conditions of the animal & 4.07 & $4.28 \mathrm{a}$ & $3.65 b$ & $3.95 b$ & $30.337 * *$ & 0.000 \\
\hline Conditions of slaughter of the animal & 3.95 & $4.58 \mathrm{a}$ & $1.98 \mathrm{c}$ & $3.98 b$ & $635.633 * *$ & 0.000 \\
\hline $\begin{array}{l}\text { Place of birth, breeding, fattening and slaughter of } \\
\text { the animal }\end{array}$ & 3.96 & $4.34 \mathrm{a}$ & $3.46 \mathrm{~b}$ & $3.66 \mathrm{~b}$ & $66.291 * *$ & 0.000 \\
\hline Production system of the animal ${ }^{1}$ & 4.42 & $4.66 \mathrm{a}$ & $4.10 \mathrm{~b}$ & $4.25 \mathrm{~b}$ & $41.857 * *$ & 0.000 \\
\hline Handling of the animal considering welfare standards & 4.50 & $4.66 \mathrm{a}$ & $4.01 \mathrm{~b}$ & $4.50 \mathrm{a}$ & $42.430 * *$ & 0.000 \\
\hline
\end{tabular}

*Different letters in the same row indicate statistically significant differences according to the Tukey test $(\mathrm{P} \leq 0.05)$. **Different letters in the same row indicate statistically significant differences according to the Tukey test $(\mathrm{P} \leq 0.001)$. ${ }^{1}$ Range fed or by concentrates, in confinement or free range. ${ }^{2}$ Statistical significance.

Segment 1: Consumers receptive to information on meat package labels. Segment 2: Consumers who reject the information about the slaughter of the animal.

Segment 3: Consumers less concerned about the information on labels.

of the animal (Realini et al., 2004; Choat et al., 2006), it is possible to suggest broadening the denominations in categorizing meat, indicating specifically if meat within a category comes from a male or a female. The high level of agreement about including labeling information about: whether handling of the animal considered animal welfare standards (4.50); the production system (4.42); and animal feeding (4.41) coincides with the concern among European consumers about having information on the attributes and credence of meat (Corcoran et al., 2001; Bernués et al., 2003a). As well, these results concur with results from earlier studies carried out in developed countries (Bernués et al., 2003b; McEachern and Seaman, 2005; María, 2006) and in Chile (Köbrich et al., 2001; Schnettler et al., 2008b) regarding a positive consumer attitude toward AW, even though Schnettler et al. (2008b) determined that only $45.7 \%$ of survey subjects in Temuco had any kind of information about AW. Since the 1990s, the literature indicates the importance of AW in the orientation of consumer preferences (Verbeke and Viaene,
1999), which has emerged as an important component in ensuring quality (Blokhuis et al., 2003). Consequently, while Decree 61 establishes that slaughterhouses should have the facilities to ensure animal welfare, consumers have not been duly informed. In this regard, Napolitano et al. (2007) determined that if meat is acceptable in sensorial terms, AW information improves consumer perceptions.

The high level of agreement about including information about the animal feed concurs with several previous studies (Glitsch, 2000; Bernués et al., 2003a; 2003b; Olaizola et al., 2005), which identify this as the most important quality attribute in relation to the safety of the product. The high value on information about the production system is in line with several studies in developed countries that indicate a growing concern among consumers about the impact of intensive production on environmental safety (Verbeke and Viaene, 1999; Bernués et al., 2003a; 2003b) and food quality (Schröder and McEachern, 2004; Olaizola et al., 2005; 
María, 2006). Consequently, it is possible to state that consumers are not indifferent to the production system or the type of feed used in the production of beef cattle, as is shown in the results obtained by Schnettler et al. (2008b) in Temuco, in which consumers considered it positive that animals are pasture fed and bred free range and consider the use of hormones and broiler litter feed as negative.

While the lower level of agreement obtained with regard to including information about the place of birth, breeding, fattening and slaughter of the animal (3.96), concurs in part with the low interest of European consumers in information on traceability (Verbeke et al., 2000; Verbeke and Ward, 2006), this result could indicate the lack of knowledge on the part of consumers about what the term traceability means. The lower level of agreement on including information about transportation conditions (4.07) and slaughter (3.95) is contrary to the high level of agreement about including whether the animal was handled with consideration of its welfare (4.5), which again reveals lack of knowledge on the theme. Nevertheless, it concurs with the results of Gellynck and Verbeke (2001) and van Rijswijk et al. (2008), which indicate that consumers do not require technical information and prefer easily understood and rapidly processed information.

\section{Consumer segments according to the utility and acceptance of information on labels}

Three consumer segments were obtained by means of cluster analysis according to the utility assigned to the information currently on meat package labels and the level of agreement with including additional information, in combined form. Significant differences were observed among the segments according to the utility assigned to the name and cooking use of the cut, nutritional content, country of origin, place of slaughter $(\mathrm{p} \leq 0.001)$, packaging and expiration date and classification of the meat $(\mathrm{p}$ $\leq 0.05$ ). Likewise, the segments presented significant differences $(p \leq 0.001)$ in the level of agreement about including the totality of additional information themes consulted (Table 2).

\section{Segment 1. Consumers receptive to the information on} meat packaging labels. Some $49.2 \%$ of consumers $(n=$ 379), assigned high utility to all of aspects of information on meat packaging labels. This was statistically similar to Segment 2 and higher than Segment 3 in relation to packaging and expiration dates $(\mathrm{P} \leq 0.05)$, utility assigned to the name of the cut, appropriate cooking use and nutritional content $(\mathrm{P} \leq 0.001)$. It was significantly higher than Segment 2 and similar to Segment 3 in the utility of information about classification $(\mathrm{P} \leq 0.05)$ and origin $(\mathrm{P}$ $\leq 0.001)$ and, significantly higher than both segments ( $\mathrm{P}$ $\leq 0.001)$ in the utility given to the place of slaughter ( $\mathrm{P} \leq$ $0.001)$. With regard to additional information, this group presented the highest level of agreement about inclusion of such information on the label, significantly higher than the other groups regarding information about animal feed, transportation conditions and slaughter, traceability and production system, and significantly higher than Segment 2 but similar to Segment 3 in the level of agreement about including a quality seal, information about the type of animal and the use of AW standards $(\mathrm{P} \leq 0.001)$.

\section{Segment 2. Consumers who reject the information} about the slaughter of the animal. Segment 2 was the minority segment, with $16.4 \%$ of consumers $(\mathrm{n}=$ 126). Statistically similar to Segment 1 and higher than Segment 3, Segment 2 assigned high utility to the date of packaging $(\mathrm{P} \leq 0.05)$, name and use of the cut $(\mathrm{P} \leq 0.001)$. It did not differ from the other two segments in the utility associated with the information about the expiration date and the nutritional content of meat. The utility assigned to the classification and country of origin of meat was high, but significantly lower than that of Segments 1 and 3. Unlike the total sample and Segment 1, this group presented indifference to information about the place of slaughter, with a significantly lower utility value than that of Segment 1, but similar to that of Segment $3(\mathrm{P} \leq 0.001)$. This segment presented the lowest level of agreement about the inclusion of additional information on meat packaging labels, significantly lower than Segments 1 and 3 regarding a quality seal, type of animal and AW standards, and similar to Segment 3 and lower than Segment 1 in agreement regarding including information about animal feed, production system, transportation conditions and traceability $(\mathrm{P} \leq 0.001)$. In regard to transportation and information about traceability, this segment showed the closest level to indifference (3.65 and 3.46; respectively), while it was the only group that showed disagreement about the inclusion of information about the slaughter of the animal (1.98), a statistically different behavior from the other two segments $(\mathrm{P} \leq 0.001)$.

Segment 3. Consumers less concerned about labeling information. This segment represented $34.4 \%$ of consumers $(n=265)$. While the utility values were within the high range with the majority of the types of information evaluated, this group assigned significantly lower utility to packaging date $(\mathrm{P} \leq 0.05)$ and name and cooking use of the cut $(\mathrm{P} \leq 0.001)$. Similarly, this segment assigned significantly lower utility to the expiration date $(\mathrm{P} \leq 0.05)$ and nutritional content $(\mathrm{P} \leq 0.001)$ compared 
to Segment 1, but not differing from Segment 2. The utility assigned to classification and country of origin was similar to that of Segment 1 and significantly higher than that of Segment $2(\mathrm{P} \leq 0.001)$. Like Segment 2, this group presented indifference to knowing the place of slaughter of the animal. With regard to additional information, this group presented a similar level of agreement to that of Segment 1 and significantly higher than that of Segment 2 on the inclusion of a quality seal and information about the type of animal and animal welfare standards, while the level of agreement regarding having information about feeding, transportation conditions, traceability and production system was similar to that of Segment 2 and lower than that of Segment 1. Regarding inclusion of information about the conditions of the slaughter of the animal, this group differed significantly from the other segments identified $(\mathrm{P} \leq 0.001)$.

From the demographic point of view, the three identified segments present significant differences in terms of gender, age, family size, presence and age of children $(P \leq 0.05)$, education and region of residence of the consumer $(\mathrm{P} \leq 0.001)$, but not in relation to occupation, socioeconomic group and urban vs. rural residence $(\mathrm{P}$ $>0.05$ ) (Table 3). The segment receptive to labeling information for meat $(49.2 \%)$ had a higher proportion of women than was expected (76.1\%), persons 55 years of age or older (13.8\%), and persons from small households $(17.8 \%)$. The segment that rejects information about the slaughter of the animal (16.4\%) presented a higher proportion of men $(35.7 \%)$, persons who completed university education (38.9\%) and residents in the BíoBío Region (60.3\%). The segment less concerned about labeling information (34.4\%) presented a lower proportion of persons belonging to families with one of two members $(7.9 \%)$ and composed only of adults $(22.6 \%)$.

The higher proportion of women in the segment receptive to the information on meat packaging labels and the higher proportion of men in the segment that rejects information about the slaughter of the animal agrees with the greater concern about the effects of intensive production systems on the environment (Alfnes, 2004) and greater sensitivity to AW detected among women (María, 2006). While the greater presence of persons 55 years of age or older in the segment receptive to the labeling information concurs with the greater concern for health and higher ethical standards at an older age (Verbeke et al., 2000), it precludes greater concern about the impact of intensive production (Bernués et al., 2003b) and greater acceptance of AW by younger persons (María, 2006). The most receptive segment to the labeled information did not present a higher educational level, in contrast to the results of research in developed countries (Grunert and Valli, 2001; Bernués et al., 2003b; Olaizola et al., 2005; María, 2006). In contrast to the greater concern about ethical and health themes detected in families with small children (under 12 years of age) in developed countries (Verbeke et al., 2000; Bernués et al., 2003a), there was no clear relationship detected between this variable and the utility and acceptance of labeled information. This suggests that the nutritional care of children is still not considered when consumers buy meat. The different composition of consumers from the two regions in the segment that reject the information about the slaughter, confirms the existence of cultural differences in perceptions about the quality of beef (Bernués et al., 2003a), which makes it necessary to carry out this type of study in different regions of the country.

Parallel to this, the identified segments presented significant differences according to the frequency of consuming beef, reading meat packaging labels before purchasing $(\mathrm{P} \leq 0.001)$ and having received information about AW ( $\mathrm{P} \leq 0.001)$ (Table 3$)$. The segment receptive to labeling information presented a higher percentage of persons who read meat packaging labels and a high proportion of persons who had previously received information about AW, which in part would explain the higher sensitivity or level of agreement about the inclusion of information on this aspect on labels. The segment that rejected information about the slaughter of the animal had a higher proportion of persons who consume beef daily and a lower percentage of persons who read meat packaging labels before buying. The segment less concerned about the information on labels had a higher proportion of persons who had not received information about AW, a low presence of persons who consume beef daily, but who consume beef more than three times a week, aspects that could explain the lower acceptance of additional information and assigned utility to the information on meat labels. These results show the importance of encouraging informational campaigns that promote the use of meat package labels by consumers and the benefits of consuming meat from animals treated according animal welfare standards, with assurance of quality and safety.

Consequently, the different agents participating in the beef industry in Chile should take advantage of the functions served by labeling, in particular product differentiation in relation to competition, by ensuring a certain level of quality (Caswell and Mojduszka, 1996; Altmann, 1997), thus improving consumer perception of nationally produced beef (Verbeke and Viaene, 1999; Bredahl, 2004). Labeling strategies should give more importance to the stimulus that affects women, who according to this study are more receptive to information and also in greater proportion purchase meat for their households (Schnettler et al., 2006). 
Table 3. Characteristics of the segments identified (\%) with statistical differences $\left(\mathrm{Chi}^{2}\right)$ obtained via cluster analysis. The Bío-Bío and La Araucanía Regions. January 2007.

\begin{tabular}{|c|c|c|c|}
\hline Sample & $\begin{array}{c}\text { Segment } 1 \\
(\mathrm{n}=379)\end{array}$ & $\begin{array}{c}\text { Segment } 2 \\
(\mathrm{n}=126)\end{array}$ & $\begin{array}{c}\text { Segment } 3 \\
(\mathrm{n}=234)\end{array}$ \\
\hline Gender & & $\mathbf{P}=\mathbf{0 . 0 3 3}$ & \\
\hline Female & 76.1 & 64.3 & 71.7 \\
\hline Male & 23.9 & 35.7 & 28.3 \\
\hline Age & & $\mathbf{P}=\mathbf{0 . 0 0 3}$ & \\
\hline$<35$ years of age & 23.9 & 39.7 & 26.0 \\
\hline $35-54$ years of age & 62.3 & 51.6 & 65.3 \\
\hline 55 or older & 13.8 & 8.7 & 8.7 \\
\hline Size of family group & & $P=0.007$ & \\
\hline $1-2$ family members & 17.8 & 12.7 & 7.9 \\
\hline 3-4 members & 48.9 & 55.6 & 58.1 \\
\hline 5 or more & 33.2 & 31.7 & 34.0 \\
\hline Age of family members & & $P=0.019$ & \\
\hline Families with children under 12 & 33.4 & 31.0 & 28.7 \\
\hline Families with children between 13 and 17 & 36.9 & 35.7 & 48.7 \\
\hline Families with only adults & 29.7 & 33.3 & 22.6 \\
\hline Education & & $P=0.001$ & \\
\hline Primary not completed & 0.5 & 1.6 & 0.4 \\
\hline Primary completed & 1.3 & 3.2 & 1.1 \\
\hline Secondary not completed & 2.1 & 3.2 & 0.8 \\
\hline Secondary completed & 36.7 & 19.0 & 39.2 \\
\hline Vocational note completed & 11.2 & 12.7 & 16.2 \\
\hline Vocational completed or university not completed & 23.4 & 21.4 & 19.2 \\
\hline University completed or more & 24.7 & 38.9 & 23.0 \\
\hline Region & & $P=0.000$ & \\
\hline Bío-Bío & 49.9 & 60.3 & 45.3 \\
\hline La Araucanía & 50.1 & 39.7 & 54.7 \\
\hline Frequency of consuming beef & & $\mathbf{P}=\mathbf{0 . 0 0 0}$ & \\
\hline Daily & 14.2 & 19.7 & 5.0 \\
\hline 3 times/week & 49.3 & 45.9 & 60.2 \\
\hline 1 time/week & 28.5 & 24.6 & 30.9 \\
\hline Occasional & 7.9 & 9.8 & 3.9 \\
\hline Read meat package labels & & $P=0.000$ & \\
\hline Yes & 95.0 & 81.7 & 92.8 \\
\hline No & 5.0 & 18.3 & 7.2 \\
\hline Has received information about $\mathrm{AW}$ & & $P=0.004$ & \\
\hline Yes & 47.2 & 34.4 & 35.8 \\
\hline No & 52.8 & 65.6 & 64.2 \\
\hline
\end{tabular}

AW: animal welfare.

\section{CONCLUSIONS}

In general, supermarket shoppers from cities of more than 100000 inhabitants from the Bío-Bío and La Araucanía Regions consider the information on beef packaging useful, highlighting the packaging and expiration dates. A high level of agreement was found on including additional information on the label regarding quality certification, production system, animal welfare and animal feed. Nevertheless, through cluster analysis consumer segments were distinguished that assign different degrees of utility to the information on labels, 
differing in their level of agreement about including additional information on credence attributes, reading labels, beef consumption and previous knowledge about animal welfare.

\section{ACKNOWLEDGEMENTS}

The results presented correspond to Project FIA-PIC-2005-1-P-010 and FONDECYT Project 1080146. We thank Ricardo Vidal for his participation in the design of the questionnaire and Lisette Vallejos, a student from the Universidad de La Frontera, for her work in the application of the surveys.

\section{RESUMEN}

Utilidad y aceptación de información en el etiquetado de la carne bovina en consumidores del sur de Chile. Considerando la importancia que han adquirido los atributos de credibilidad (sistema de producción, bienestar animal, trazabilidad, entre otros) en el consumo de carne de los países desarrollados, aspectos que deben ser informados mediante el etiquetado, se realizó una encuesta personal a 770 consumidores de las Regiones del Bío-Bío y La Araucanía de Chile, para determinar la utilidad de la información contenida en el etiquetado, la aceptación de información referida a atributos de credibilidad, y distinguir diferentes segmentos de consumidores. La fecha de envasado y caducidad fueron los aspectos más útiles dentro de la información actual. El mayor grado de acuerdo respecto a información que se debiera incluir correspondió a sello de calidad, tipo de animal, manejo considerando bienestar animal, sistema de producción y alimentación. Mediante análisis cluster se distinguieron tres segmentos, el más numeroso $(49,2 \%)$ mostró el mayor grado de acuerdo con incluir información de alimentación, condiciones de transporte y faenamiento, trazabilidad, y sistema de producción. El segundo grupo $(34,4 \%)$ presentó indiferencia respecto de información de transporte, faenamiento y trazabilidad. El segmento minoritario (16,4\%) estuvo en desacuerdo con incluir información del faenamiento. Por tanto, la información actual presente en el etiquetado de la carne es útil para los consumidores, quienes además valorarían contar con información de atributos de credibilidad asociados a la producción del ganado, como el sistema de producción, alimentación y bienestar animal,

Palabras clave: carne bovina, etiqueta, bienestar animal, sistemas de producción, trazabilidad.

\section{LITERATURE CITED}

Adimark. 2004. Mapa socioeconómico de Chile. Adimark, Santiago, Chile. Available at http://www.adimark.cl/ medios/estudios/Mapa_Socioeconomico_de_Chile. pdf (accessed 20 October 2005).

Alfnes, F. 2004 Stated preferences for imported and hormone-treated beef: application of a mixed logit model. Eur. Rev. Agric. Econ. 31:19-37.

Altmann, M. 1997. Product policy. p. 279-294. In D. Padberg, C. Titson, and L. Albisu (eds.) Agro-food marketing. CAB International, Wallingford, UK.

Beardsworth, A., A. Bryman, T. Keil, J. Goode, C. Haslam, and E. Lancashire. 2002. Women, men and food: the significance of gender for nutritional attitudes and choices. Br. Food J. 107:470-491.

Bernués, A., A. Olaizola, and K. Corcoran. 2003a. Labelling information demanded by European consumers and relationships with purchasing motives, quality and safety of meat. Meat Sci. 65:1095-1106.

Bernués, A., A. Olaizola, and K. Corcoran. 2003b. Extrinsic attributes of red meat as indicators of quality in Europe: an application for market segmentation. Food Qual. Prefer. 14:265-276.

Blokhuis, H.J., R.B. Jones, R. Geers, M. Miele, and I. Veissier. 2003. Measuring and monitoring animal welfare: transparency in the food product quality chain. Anim. Welfare 12:445-455.

Bredahl, L. 2004. Cue utilization and quality perception with regard to branded beef. Food Qual. Pref. 15:65-75.

Caswell, J.A., and E.M. Mojduszka. 1996. Using informational labelling to influence the market for quality in food products. Am. J. Agric. Econ. 78:12481253.

Corcoran, K., A. Bernués, E. Manrique, M.T. Pacchioli, R. Baines, and J.P. Boutonnet. 2001. Current consumer attitudes towards lamb and beef in Europe. Options Méditerranéennes A46:75-79.

Choat, W.T., J.A. Paterson, B.M. Rainey, M.C. King, G.C. Smith, K.E. Belk, and R.J. Lipsey. 2006. The effects of cattle sex on carcass characteristics and longissimus muscle palatability. J. Anim. Sci. 84:1820-1826.

FAENACAR. 2004. Nuevo Reglamento de Mataderos, 9 septiembre 2004. Reglamento sobre Estructura y Funcionamiento de Mataderos, Cámaras Frigoríficas y Plantas de Desposte y Fija Equipamiento Mínimo de tales Establecimientos. Asociación Gremial de Plantas Faenadoras Frigoríficas de Carnes de Chile, Santiago, Chile. Available at http://www.faenacar.cl/ UserFiles/File/legales/NuevoReglamentoMataderos. pdf (accessed 26 November 2008). 
Fernández, A. 2002. Investigación y técnicas de mercado. 273 p. Editorial Esic, Madrid, España.

Gellynck, X., and W. Verbeke. 2001. Consumer perception of traceability in the meat chain. Agrarwirtschaft 50:368-374.

Glitsch, K. 2000. Consumer perceptions of fresh meat quality: cross-national comparison. Br. Food J. 102:177-194.

Grunert, K.G., and C. Valli. 2001. Designer-made meat and dairy products: consumer-led product development. Livest. Prod. Sci. 72:83-98.

Hair, J., R. Anderson, R. Tatham, y W. Black. 1999. Análisis multivariante. Otero. 832 p. $5^{\text {a }}$ ed. Prentice Hall Internacional, Madrid, España.

INE. 2003. Censo 2002. Resultados Volumen I: Población; País-Región. 356 p. Instituto Nacional de Estadísticas (INE), Gobierno de Chile, Santiago, Chile.

Kinnear, T.C., y J.R. Taylor. 1989. Investigación de mercados. 335 p. $3^{\text {a }}$ ed. McGraw-Hill, Bogotá, Colombia.

Köbrich, K., M. Maino, y C. Díaz. 2001. El bienestar animal como un atributo de diferenciación en la compra de alimentos de origen animal. Econ. Agrar. 6:251-260.

Kotler, P. 1997. Marketing management: analysis, planning, implementation and control. 756 p. $7^{\mathrm{a}}$ ed. Prentice Hall International, New Jersey, USA.

Lea, P., M. Rodbotten, and. T. Naes. 1997. Analysis of variance for sensory data. 102 p. Wiley, Chichester, UK.

María, G.A. 2006. Public perception of farm animal welfare in Spain. Livest. Sci. 103:250-256.

McEachern, M.G., and C. Seaman. 2005. Consumer perception of meat production. Br. Food J. 107:572593.

Napolitano, F., G. Caporale, A. Carlucci, and E. Monteleone. 2007. Effect of information about animal welfare and product nutritional properties on acceptability of meat from Podolian cattle. Food Qual. Prefer. 18:305-312.

Olaizola, A., Z. Whebi, and E. Manrique. 2005. Quality perception and consumer attitudes to "specific quality beef” in Aragón, Spain. Span. J. Agric. Res. 3:418428.

Oliver, M., G. Nute, I. Font, M. Furnols, R. San Julián, M. Campo, et al. 2006. Eating quality for beef, from different production system, assessed by German, Spanish and British consumers. Meat Sci. 74:435-442.

Realini, C., S. Duckett, G. Brito, M. Dalla Rizza, and D. de Mattos. 2004. Effect of pasture vs. concentrate feeding with or without antioxidants on carcass characteristics, fatty acid composition, and quality of Uruguayan beef. Meat Sci. 66:567-577.
Roosen, J., J.L. Lusk, and J.A. Fox. 2003. Consumer demand for and attitudes toward alternative beef labeling strategies in France, Germany and the UK. Agribusiness 19:77-90.

SAG. 2008. Reglamento General del Sistema de Clasificación de Ganado, Tipificación, Marca y Comercialización de Carne Bovina. Texto consolidado. Servicio Agrícola y Ganadero (SAG), Santiago, Chile. Available at http://www.sag.gob.cl/common/asp/ pagAtachadorVisualizador.asp? $\arg$ CryptedData $=\mathrm{GP} 1$ TkTXdhRJAS2Wp3v88hLh8Ob3rW0mc\&argModo= inline $\& \arg$ Origen $=$ BD\&argFlagYaGrabados $=\& \arg A r$ chivoId=1945 (accessed 26 November 2008).

Scheaffer, R., W. Mendwenhall, y L. Ott. 1996. Elementos de muestreo. 321 p. Grupo Editorial Iberoamericana, Ciudad de México, México.

Schnettler, B., O. Manquilef, y H. Miranda. 2004. Atributos valorados en la selección de carne bovina en supermercados de Temuco, IX Región de Chile. Cien. Inv. Agr. 31:91-100.

Schnettler, B., O. Manquilef, y H. Miranda. 2006. Hábitos de consumo de carne bovina en Temuco, IX Región de Chile. Idesia 24:15-23.

Schnettler, B., D. Ruiz, O. Sepulveda, and N. Sepulveda. 2008a. Importance of the country of origin in food consumption in a developing country. Food Qual. Pref. 19:372-382.

Schnettler, B., R. Vidal, R. Silva, L. Vallejos, and N. Sepulveda. 2008b. Consumer perception of animal welfare and livestock production in the Araucanía Region, Chile. Chilean J. Agric. Res. 68:80-93.

Schröeder, M.J.A., and M.G. McEachern. 2004. Consumer value conflicts surrounding ethical food purchase decisions: a focus on animal welfare. Int. J. Consum. Stud. 28:168-177.

SPSS. 2005. Statistical Package for the Social Sciences (SPSS) for Windows. Version 14.0. SPSS, Chicago, Illinois, USA.

Van Rijswijk, W., L. Frewer, D. Menozzi, and G. Faioli. 2008. Consumer perceptions of traceability: A crossnational comparison of the associated benefits. Food Qual. Prefer. 19:452-464.

Verbeke, W., and J. Viaene. 1999. Beliefs, attitude and behavior towards fresh meat consumption in Belgium: empirical evidence from a consumer survey. Food Qual. Prefer. 10:437-445.

Verbeke, W., R. Ward, and J. Viaene. 2000. Probit analysis of fresh meat consumption in Belgium: exploring BSE and television communication impact. Agribusiness 16:215-234.

Verbeke, W., and R. Ward. 2006. Consumer interest in information cues denoting quality, traceability and origin: An application of ordered probit models to beef labels. Food Qual. Prefer. 17:453-467. 